\title{
Book Review: Warning Signs of Genocide: An Anthropological Perspective
}

Christopher Powell Ph.D.

Ryerson University

Follow this and additional works at: https://digitalcommons.usf.edu/gsp

\section{Recommended Citation}

Powell, Christopher Ph.D. (2015) "Book Review: Warning Signs of Genocide: An Anthropological Perspective," Genocide Studies and Prevention: An International Journal: Vol. 9: Iss. 1: 119-121. DOI:

http://dx.doi.org/10.5038/1911-9933.9.1.1288

Available at: https://digitalcommons.usf.edu/gsp/vol9/iss1/13

This Book Review is brought to you for free and open access by the Open Access Journals at Digital Commons @ University of South Florida. It has been accepted for inclusion in Genocide Studies and Prevention: An International Journal by an authorized editor of Digital Commons @ University of South Florida. For more information, please contact digitalcommons@usf.edu. 


\title{
Book Review: Warning Signs of Genocide: An Anthropological Perspective
}

\author{
Christopher Powell \\ Ryerson University \\ Toronto, ON, Canada
}

Warning Signs of Genocide: An Anthropological Perspective

E. N. Anderson and Barbara A. Anderson

Lanham: Lexington Books, 2013 215pp, US\$ 39.99

Reviewed by Christopher Powell

Ryerson University, Toronto, ON, Canada

The search for predictors of genocide is integral to the efforts of scholar-activists to prevent and ultimately end genocidal violence. Any set of such predictors necessarily presupposes, or at least implies, a definite notion of what genocide is and a theory of how it takes place. In The Warning Signs of Genocide: An Anthropological Perspective, authors E.N. Anderson and Barbara A. Anderson attempt precisely this. They conceptualize genocide in terms similar to Rudolph Rummel's concept of democide, propose an etiological theory of genocide grounded in evolutionary psychology, infer the warning signs of genocide in the making, and propose remedial measures for preventing genocide while its conditions of possibility are still being established. They also offer their own list of countries at risk of committing genocide, with some surprising inclusions. The book is flawed and its argument is problematic in several ways, but it offers interesting insights along the way and makes a worthwhile contribution to further attempts to formulate a preventative theory of genocide.

Anderson and Anderson begin by recognizing that Ben Kiernan's Blood and Soil and Stephen Pinker's The Better Angels of Our Nature, both of which appeared during the writing of this book, serve as major interlocutors and indeed forced "the biggest rewriting projects the two of us have ever had to undertake in our rather long professional lives!" (p. xii). Indeed, in one sense the entire book reads, and succeeds best, as Rousseauian rebuttal of Pinker's Hobbesian take on how human nature contributes to violence. Anderson and Anderson argue forcefully that genocide happens not because human nature is competitive and antisocial, but precisely because human beings are innately sociable, solidary, and moral. Human beings, the authors argue, evolved to live solidaristically in bands of fifty to one hundred and fifty individuals. As a result we have an innate psychological disposition to cooperative group behaviour but also an innate psychological capacity to fear anything which we perceive as a threat to our group, and to convert that fear into hatred which motivates us to destroy the source of the threat. Individual fear and hatred, however, cannot produce genocide, which requires a level of social organization and coordination far in excess of that which obtained among our ancestors in the African savannah. For fear and hatred to lead to genocide, first a group must be defined as Other in a rigid and stereotyped way, then "opportunistic politicians" must exploit this situation by inflaming individual feelings to make them the dominant feelings of the group as a whole. This collective hatred and fear are institutionally reinforced when political leaders form a "thuggish band of enforcers," which may consist of armed gangs or paramilitaries or which may consist of the nation's armed forces as a whole. Finally, "when war or extreme unrest breaks out, insecure but autocratic elites use such means to try to control the situation" (p. 119). The escalation of this use of violence against designated social others to maintain autocratic power is what produces genocide.

On the basis of this model the authors make predictions about countries at various levels of risk for genocide. Examples of "extreme immediate risk" are Congo-Brazzaville, DR Congo, Egypt, Indonesia, Myanmar, Niger, Nigeria, and Sudan. Longer-term risks include Burundi, China, Eritrea, Guatemala, Iran, Iraq, Mali, North Korea, and Pakistan. Beyond this, the authors assess various levels of risk for Colombia, Central America, much of sub-Saharan Africa, Russia and Eastern Europe, Turkey, and India, Bangladesh, and Nepal. 
Provocatively, Anderson and Anderson argue that conditions for genocide are emerging within the United States itself. They argue that "fear-based ideas - hatred of women and minorities and glorification of strength and bigness" have become central to American conservatism (p. 124); this escalating collective fear and hatred, along with increasingly rigid out-group status assigned to subordinate groups such as Hispanics, non-Hispanic illegal immigrants, labour unions, women, homosexuals, and so on could become the basis for institutionalized collective hatred which could lead to genocide.

The key point which Anderson and Anderson stress is that the roots of, and predictors for, genocide lie not in ideology, whether of blood and soil, revolution, or anything else, but in a socially shared emotion and the translation of that emotion into institutionalized violence.

The preventative measures that the book recommends focus on addressing the causes of fear and hatred of social others and on preventing the calcification of individual feelings into collective feelings and institutions. These measures revolve around five key concerns, of which the first, "dealing with hatred and the political exploitation of it," is the most directly justified by the book's theoretical model. If the roots of genocide lie in the social fears converted into group hatreds, it follows logically that, for instance, education "to teach people to cope proactively with trouble and to be independent thinkers" (p. 138) and to "stop defining groups as absolute, essential entities" (p. 136) should be part of an effective prevention, as would some constructive engagement with religion (p. 139). Other measures that the authors recommend, such as preventing economic downturns and fostering democratic accountability, address the social circumstances that generate social fears or that enable the political mobilization of fear and hatred by elites.

The authors' recommendations are ambitious, even utopian, implying a wholesale transformation of global society along social liberal lines. This broad reach exemplifies some of the key strengths and weaknesses of the book. On the one hand, it is good to see explicit connections made between genocide prevention and related projects like human rights, human security, and multiculturalism. On the other hand, the authors make no attempt to explain which actors will implement their recommendations or where the political will to do so will come from.

The book's other contributions are similarly uneven. On the one hand, there are many specific insights to be had, small and large. For example, the observation that "genocide often bears an uncanny resemblance to domestic violence, and also to schoolyard bullying" (p. 4, see also pp. 87-88) suggests an interesting connection or isomorphism between social processes at micro and macro scales. The same is true for the argument that "what has been called 'dehumanization' is really a process of developing and consolidating group rejection or barriers" (p. 61), and for the examination of the neurobiology of fear and its effects on rational judgment (p. 17-18). The general proposition that genocide relies on the collective mobilization of particular emotional orientations rather than on particular and characteristic ideological orientations opens up an interesting line of inquiry into the relationship between genocidal projects and embodied dispositions.

On the other hand, the book offers no theoretically informed analysis of power, of difference, of the modern nation-state or the modern world-system, or of any particular social institutions. In this sense genocide appears entirely contingent: for contingent reasons such as a sudden loss of status by a dominant group, individuals become fearful and prone to hate; and for additionally contingent reasons some political leaders try to capitalize on this fear and hatred to their own advantage; and for contingent reasons this succeeds and people buy in to a genocidal agenda.

One of the weakest parts of the book comes in its opening chapter. Anderson and Anderson define 'genocide' very narrowly - as the "systematic, cold-blooded, bureaucratically administered extermination of entire ethnic, religious, or political groups, by their own national governments, in the absence of anything that a rational external observer could consider an adequate reason" (p. 6). This model closely resembles Rudolph Rummel's concept of 'democide', as the authors acknowledge. But aside from a few brief and dismissive mentions, Anderson and Anderson ignore the entire definitional debate of the past twenty years, including the entire line of scholarship represented by Moses, Woolford, and others who argue for treating cultural extermination of indigenous peoples as genocide. Martin Shaw's pivotal What is Genocide? is nowhere discussed. Lemkin's definition is invoked as gospel but Lemkin's writing are not examined and the authors miss important aspects of what Lemkin had to say. 
Nor is there a substantive engagement with other social scientific models aimed at predicting genocides. Gregory Stanton's predictive model is referenced briefly in its 1996 articulation, but his subsequent revision of that conception into a ten-stage model is not critiqued. Michael Mann's rigorous and detailed predictive model in The Dark Side of Democracy is not even mentioned despite its obvious direct relevance to the authors' project. Aside from Kiernan and Pinker, in fact, little recent work is engaged with. As a result, the historical overview in Chapter 6 feels like it could have been written twenty years ago, and Appendix I, "Statistics of Genocide, With Risk Factors," does not have the methodological rigour to live up to its subtitle.

Overall, however, Warning Signs of Genocide makes a very specific but worthwhile contribution to genocide scholarship. The project of developing a theoretical model of genocide capable of predicting the sociogenesis of genocidal violence in its early stages and prescribing effective measures to halt or divert this process is large and complex, but such a project must account for the interplay between objective social structures and subjective individual motivations. The argument in Warning Signs of Genocide provides one piece of that puzzle. There are gaps in its scholarship, one gets the sense that the authors don't have a strong understanding of social or cultural theory, and the conception of genocide is much too narrow. But Anderson and Anderson do succeed in offering a plausible account of certain connections between human evolution, emotion, and social structure. This account could be useful for a more robust and sociologically informed theory of genocide. 